Canadian

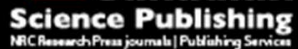

Canadian Journal of Earth Sciences Revue canadienne des sciences de la Terre

\title{
An overview of Chinese Silurian acritarch research
}

\begin{tabular}{|r|l|}
\hline Journal: & Canadian Journal of Earth Sciences \\
\hline Manuscript ID & cjes-2015-0215.R2 \\
\hline Manuscript Type: & Article \\
\hline Complete List of Authors: & $\begin{array}{l}\text { Yan, Kui; Nanjing Institute of Geology and Palaeontology, Chinese } \\
\text { Academy of Sciences } \\
\text { Li, Jun; Nanjing Institute of Geology and Palaeontology, Chinese Academy } \\
\text { of Sciences } \\
\text { Servais, Thomas; UMR 8198 Evo-Eco-Paléo CNRS, Université de Lille1 }\end{array}$ \\
\hline Keyword: & \begin{tabular}{l} 
acritarchs, Silurian, China \\
\hline
\end{tabular} \\
\hline
\end{tabular}

SCHOLARONE ${ }^{m}$

Manuscripts 
9

10

11

12

13

14

15

16

17

18

19

20

21

22

\section{An overview of Chinese Silurian acritarch research}

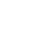

\section{Kui Yan $^{1}$, Jun Li ${ }^{1}$, Thomas Servais ${ }^{2}$}

${ }^{1}$ Nanjing Institute of Geology and Palaeontology, Chinese Academy of Sciences, East

Beijing Road, 210008 Nanjing, China

${ }^{2}$ UMR 8198 Evo-Eco-Paléo CNRS, Université de Lille1, SN5, USTL, F-59655

Villeneuve d'Ascq, France

Corresponding author: Kui Yan (e-mail: kuiyan@nigpas.ac.cn).

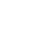

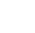

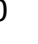

(1)

2

3

(14)

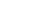



12

\title{
An overview of Chinese Silurian acritarch research
}

\author{
Kui Yan ${ }^{1}$, Jun Li ${ }^{1}$, Thomas Servais ${ }^{2}$
}

Abstract: The present paper reviews all investigations of Silurian acritarchs of China.

Since Silurian acritarchs were first reported from China in 1978, significant progress has been made in Chinese Silurian acritarch research. A total of 30 scientific articles and theses have been published on Silurian acritarchs from China. A majority of these papers recorded acritarchs from South China and most Silurian acritarch studies concentrated on the Llandovery. Two papers describing material thought to be Silurian have since been shown to be Ordovician acritarch assemblages. We have updated the systematics of the taxa in these reported assemblages and documented their biostratigraphic distribution within China. Investigations of Silurian acritarchs, however, are still very limited and more research is needed for systematic, biostratigraphic, and palaeoecological interpretations.

Keywords: acritarchs, Silurian, China

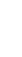

\section{1} 3 44 


\section{Introduction}

Although the Silurian is the shortest period of the Palaeozoic, it is a fascinating interval for geology, biostratigraphy, biogeography, palaeoecology, geochemistry and tectonics (Rong and Chen 2000). After the End-Ordovician extinction event, a rapid recovery in biodiversity occurred during the Silurian. The Silurian is also important in the history of the colonization of land by plants, the closure of the Iapetus Ocean, and the narrowing of the Rheic Ocean (Melchin et al. 2012). Compared to the Ordovician, biotic provincialism during the Silurian was relatively low (Melchin et al. 2012), but the diversity of acritarchs was still high (e.g., Tappan and Loeblich 1973; Strother 1996). As the primary producers, the acritarchs played an important role in the Silurian oceans, and data from China thus make a significant contribution to the understanding of Silurian phytoplankton.

Silurian acritarch research in China started relatively recently. The first article was published in 1978 (Zhong 1978). Since then, 30 papers have concentrated on Silurian acritarch assemblages in China. Compared with the Ordovician, Silurian research intensity is fairly low, but it is still important for biostratigraphic correlation, palaeoecological interpretations, and global palaeobiogeographic scenarios of the Silurian. Most Silurian acritarch research in China was published in Chinese and papers were rarely submitted to international journals. Although Li et al. (2002) reviewed the Palaeozoic acritarch research in China, specialists outside of China have still largely ignored Chinese Silurian data. The objective of the present paper is to review the progress of Silurian acritarch studies from China in more detail and to 
bring this work to the attention of the international community.

\section{Silurian geology of China}

The research on the Silurian of China can be traced back to the 1880s (Rong and Chen 1990). After this initial period of investigation, Silurian studies have been focused mainly on palaeontology, stratigraphy and palaeogeography. Yin (1949) published the first Early Silurian palaeogeographic maps of South China, and a large number of researchers followed by publishing Silurian palaeogeographic maps from almost all regions of China. Rong and Chen (1990) provided the first overview of Chinese Silurian research and its history. In the 1990s, new data on the Silurian of China and new regional or local palaeogeographic maps for different Silurian epochs have been published (Rong et al. 2003; Rong and Chen 2003). Subsequently, Rong et al. (2003) and Rong and Chen (2003) summarized Silurian studies on lithofacies, biofacies, biostratigraphy and palaeogeography from China and provided a palaeogeographic map to illustrate the division of tectonic units and their development in the Silurian of China based on previous studies.

Many specialists have noted that the tectonic framework of Silurian China is complex (e.g., Mu et al. 1986). As in the Ordovician, at least eight palaeoplates existed within the Silurian of China (Rong and Chen 2003), including South China, North China, Tarim, Tibet, Sibumasu, Indochina, Qaidam, the Hinggan-Altai Block, Kazakhstan (including the Jungar Block), the Yunkai Block, the Song-Gan Block, and the Alxa Block (Rong and Chen 2003) (Fig.1). Torsvik and Cocks (2013) published more 
recent global palaeogeographical reconstructions for the Cambrian to lower Devonian.

The reader is refered to Rong et al. (2003) and Torsvik and Cocks (2013) to

understand the palaeogeographical development of China during the Silurian.

\section{Silurian stratigraphy of China}

The Chinese Silurian stratigraphic correlation frameworks have been established based on graptolite and conodont biostratigraphy (Rong et al. 2003). Other fossil groups, such as chitinozoans and acritarchs, are also used for correlation. Figure 2 shows a simplified stratigraphic framework that we use herein for correlation.

\section{Silurian acritarch investigations in China}

General introduction

Thirty reports of Chinese Silurian acritarchs have been published since 1978. From the late 1970 s to the 1990 s, the number of publications increased to 11 , but only five appeared during the 2000s. Since 2010, five papers have documented Silurian acritarchs in China. In addition, several unpublished theses reported Silurian acritarchs in China, although most of them just provided taxonomy lists, and only two theses provided plates of acritarch assemblages (e.g., Guo 2012; Zhou 2014).

The published papers have reported Chinese acritarchs from the Silurian of South China, the Hainan Block, North China, the Sibumasu and Tarim palaeoplates and the Junggar Block (Fig 1). As is the case for the rest of the Palaeozoic (Li et al. 2002), most researchers focused their studies on the Silurian acritarch assemblages from 
111 South China, with 22 papers reporting acritarch assemblages from this part of the

112 country. Three papers describe acritarch assemblages from the Tarim Palaeoplate.

113 Two publications concern the material from the Junggar Block, only one paper deals

114 with the acritarchs of Sibumasu, one paper deals with acritarchs of the North China

115 Palaeoplate, and another one with those of the Hainan Block. Most papers are

116 concentrated on biostratigraphy, and only eight papers provide some systematic

117 investigations with photographic plates (Fang 1989; Fang and He 1988; Gao and Ye

118 1987; Li and Wang 1997; Li et al. 1997; Xing and Liu 1985; Ye 1984; Zhong 1978);

119 seven papers just provide a list of acritarch assemblages without photomicrographs

120 (Fang and Hou 1988; Liu 1993; Wang and Zhang 1985; Wang et al. 1988; Yan 1991,

121 1992; Yao et al. 2006); and two papers only mentioned acritarchs without a taxon list

122 (Li 1990; Wang and Ouyang 1997). Some papers only recognized one or two

123 acritarch taxa (e.g., Wang et al. 2005; Tang et al. 2015).

124 In terms of time intervals, 18 papers reported acritarchs from the Llandovery, one

125 from the Wenlock, four from the Ludlow, five from the Pridoli (Fig. 3) and two

126 papers have since been shown to document acritarchs from Ordovician. Because some

127 papers reported Silurian acritarch assemblages in China without independent

128 biostratigraphic control, new evidence has provided more accurate biostratigraphic

129 correlation, and we will discuss these in the following sections pertaining to different

130 regions.

131

132

Biostratigraphy 
133

134

We revise all acritarch taxa reported from Chinese Silurian literature, following Fensome et al. (1990), to remove the invalid taxa and combine taxonomic synonyms. Sixty-eight genera and 226 species have been reported and their stratigraphic distributions are shown in the Appendix. General biostratigrapic studies of the Silurian of China were reviewed in detail by Rong et al. (2003) and this is helpful for acritarch specialists for correlation of Silurian acritarch stratigraphy in China. Most Silurian palynology researchers in China have correlated their acritarch assemblages to each other and to those in Europe and North America. Although several acritarch taxa have been shown to be useful for Silurian biostratigraphic correlation in China, study of the Silurian acritarch biostratigraphic sequence of China is still far from complete. Some taxa are distributed in the strata of both the Ordovician and Silurian, such as Dactylofusa cabottii, Leiofusa tanaocyta, Leiosphaeridia laevigata, L. microcystis, L. wenlockia, and Strophomorpha ovata. Although Dactylofusa cabottii was first found in the Late Ordovician, it is the most common taxon present in the Silurian of China, and has been used as an index taxon of the Silurian along with other evidence, such as chitinozoans and spores. Some acritarch taxa discussed for stratigraphic correlation are restricted to the Silurian, such as Deunffia, Domasia, Elektoriskos pogonius, Helosphaeridium clavispinulosum, Micrhystridium stellatum, and Tylotopalla caelamenicutis.

Biogeography and palaeoenvironment

Cramer (1971) and Cramer \& Díez (1972, 1974a, b) provided a model for the 
155

156

157

158

159

160

161

162

163

164

165

166

167

168

169

170

171

172

173

174

175

176

distribution of Silurian acritarchs, represented by six principal acritarch biofacies. Le

Hérissé and Gourvennec (1995) re-evaluated four principal acritarch biofacies (the

Neoveryhachium carminae facies, the Deunffia facies, the Domasia facies and the

Pulvinosphaeridium-Estiastra facies) of Cramer's model, and subsequently Le

Hérissé et al. (1997) analysed the acritarch biogeography of the late Silurian. More

recently, Molyneux et al. (2013) reviewed Silurian acritarch biogeographical studies,

and pointed out that the distribution of mid Silurian acritarch biofacies were

controlled by palaeoenvironment rather than biogeography. According to Le Hérissé

and Gourvennec (1995), the acritarch assemblage from South China (based on Fang

1989) was similar to that of Libya and Jordan because of the presence of Dactylofusa

estillis. Deunffia and Domasia were important in Cramer's model and were

considered to be representative of outer-shelf environments. Deunffia was reported in

South China (Location 1 and 4) and Junggar (Location 18), and Domasia was

reported in South China (Location 1 and 4). Dactylofusa cabottii was the most

common taxon present in the Silurian of China (Location 1, 4, 6, 9, 10, 11, 13, and

16), and it is considered to be an index taxon of shallow water (Li et al. 2006). As an

example of a palaeoenvironmental application, a regressive sequence was reported by

Yan et al. (2011) based on acritarch assemblage changes.

\section{South China}

The Silurian of South China can be palaeogeographically divided into the Yangtze

Platform, the Jiangnan Belt, and the Cathaysian Land. The Yangtze Platform consists 
177 of the Upper Yangtze and Lower Yangtze regions (Rong and Chen 2003). A large

178 majority of the papers on Silurian acritarchs have focused on the assemblages from South China. Therefore, Silurian acritarchs from the Yangtze Platform are much better known than those of any other region of China.

Five papers have described the Silurian acritarch assemblages from the Jiangnan Belt in Zhejiang Province (Fig 1, Location 1). Yin and He (2000) identified 37 genera of acritarchs, including 40 species and 16 additional species in open nomenclature from the latest Ordovician to early Silurian in Zhejiang. Fang and He (1988) and Yan (1991, 1992) reported an acritarch assemblage from the Tangjiawu Formation in Zhejiang, which is dominated by Dactylofusa cabottii and Leiosphaeridia wenlockia. Yan et al. (2011) summarized their Early Palaeozoic palynomorph (including acritarchs and cryptospores) study from Zhejiang and established nine palynomorph assemblages from the Cambrian to the Silurian. Four of their palynomorph assemblages were considered Silurian: the Retisphaeridium-Dyadospora-Tetrahedraletes assemblage in the Xiaxiang Formation; the Nodospora-Tetrahedraletes-Baltisphaeridium assemblage in the Helixi Formation; the Tetrahedraletes-Dactylofusa-Leprotolypa in the Kangshan Formation; and the Dactylofusa-Strophomorpha-Leiofusa in the Tangjiawu Formation.

Three papers reported acritarchs from the Lower Yangtze region. Li et al. (2000) and Wang and $\mathrm{Li}$ (2001) described palynomorph assemblages with acritarchs, dominated by Dactylofusa cabottii, trilete spores, plant fragments, chitinozoans and scolecodonts, and referred it to the late Ludlow-early Pridoli (Fig 1, Location 11). Zhou et al. (2013) 
199

200

201

202

203

204

205

206

207

208

209

210

211

212

213

214

215

216

217

218

219

220

found some poorly preserved acritarchs, including Leiosphaeridia,

Multiplicisphaeridium and Solisphaeridium, in the Xikeng Formation from Jiujiang,

Jiangxi (Fig 1, Location 7).

Zhong (1978) first reported acritarchs from the Silurian of China and described some

sphaeromorphs in Zigui, Hubei (Fig 1, Location 2). Subsequently, Xing and Liu (1985)

described an acritarch assemblage in the Lungmachi and Lojoping formations from

the same area.

Wang and Zhang (1985) and Wang et al. (1988) described the Xiushan and Xiaoxiyu

formations and discussed their geological age (Fig 1, Location 6). They listed all taxa

that they found, including 15 genera of acritarchs. They interpreted the ages of the

Xiushan and the Xiaoxiyu formations as Telychian and Wenlock respectively. Wang et

al. (2010) revised the Xiaoxiyu Formation and subdivided it into two parts: the Xiaoxi

Formation (the original name of the Xiaoxiyu Formation) in the upper part and the

Huixingshao Formation in the lower part. They also indicated that the Xiaoxi

Formation is of Ludlow-Pridoli age, and the Huixingshao Formation is late Telychian

in age.

The Silurian acritarch assemblages from Qijiang area (Chongqing) were described by

Fang and Hou (1988) and Fang (1989) (Fig 1, Location 4). Twenty-eight genera and

21 species were identified from the Lungmachi, Shihniulan and Hanchiatien

formations, indicating a Llandovery age. Dactylofusa cabottii was the only acritach

taxon found in the Xiaoxi Formation in Xiushan, Chongqing (Wang et al. 2011) (Fig 1,

Location 10) and Guangyuan, Sichuan (Wang et al. 2005) (Fig 1, Location 9). 
221

222

223

224

225

226

227

228

229

230

231

232

Eleven genera and 21 species of acritarchs were described from the Ningqiang

Formation from Ningqiang, Shaanxi (Li and Wang 1997) (Fig 1, Location 5).

Recently, Tang et al. (2015) reported some graphitized specimens of Synsphaeridium from the Wuxiahe Formation in the Ziyang-Langao Region, Shaanxi (Fig 1, Location 8).

Silurian-Devonian boundary palynomorphs from Qujing were recorded by Tian et al. (2011) (Fig 1, Location 13). Fourteen species assigned to 11 genera of acritarchs from the upper Yulungssu Formation, Xiaxishancun Formation, and the lower-middle parts of the Xitun Formation were recognized and attributed to the Silurian.

On the western margin of the South China Palaeoplate, Gao and Ye (1987) described a palynomorph assemblage from the upper Silurian to Middle Devonian in Zoige and Tewo of the West Qinling Mountains (Fig 1, Location 12). This assemblage is dominated by spores, and contains 7 genera and 8 species of acritarchs.

Some papers reported Silurian acritarchs from South China with photomicrographs, but no taxon names were provided (Li 1990; Wang and Ouyang 1997).

\section{Hainan Block}

The Hainan Block has been considered as a part of Indochina Palaeoplate (Rong et al. 2003). Silurian acritarchs were found in Hainan block, with assemblages dominated by sphaeromorphs and acanthomorphs (Liu 1993) (Fig 1, Location 3). 
243 The Yunnan Province includes three palaeoplates during the Silurian: South China,

244 Sibumasu and Indochina. One paper reported an acritarch assemblage from the

245 Silurian of Sibumasu (Gao 1996) (Fig 1, Location 14). Three spore assemblage zones

246 were recognized from the late Silurian to the Early Devonian of Shidian (Gao 1996)

247 and these assemblages also include acritarchs. The SN (Apiculiretusispora

248 spicula-Emphanisporites neglectus) Zone was considered to be a late Silurian spore

249 assemblage zone and it is accompanied by acritarch taxa, including Leiosphaeridia,

250 Micrhystridium and Lophosphaeridium.

251

252 North China

253 No Silurian strata have been found in the North China platform, but some were

254 recorded on the margin of the North China Palaeoplate (Rong and Chen 2003). Only a

255 single paper has described an acritarch assemblage from North China, from the

256 southeast margin of the Ordos basin (Yin et al. 1993) (Fig 1, Location 15). The

257 assemblage, which is from the Dongzhuang Shale, includes 20 genera and 26 species

258 and is dominated by Dactylofusa cabottii and Leiosphaeridia, which have been

259 considered to be indicative of a Llandovery to Wenlock age. However, more recent,

260 unpublished studies by ourselves and other researchers, including $\mathrm{U}-\mathrm{Pb}$ zircon

261 chronostratigraphy, acritarch and chitinozoan analyses from the same section, imply

262 that the Dongzhuang Shale is of Late Ordovician age.

263

264 Tarim 
265 Silurian strata occur on the margin of the Tarim Basin (Rong and Chen 2003) and the

266 Karakum Region is considered to have been united with the Tarim Palaeoplate during 267 the Silurian (Rong et al. 2003). Tarim is considered to be close to South China during

268 the Silurian because their shelly faunas were similar (Rong and Chen 2003). Three

269 papers mentioned Silurian acritarch assemblages in the Tarim Palaeoplate. Li et al.

270 (1997) described an acritarch assemblage together with scolecodonts and cryptospores

271 from the Tataertage Formation in the Dawangou section, Kalping (Fig 1, Location 16).

272 The assemblage contains the acritarchs Dactylofusa cabottii, Gloeocapsomorpha

273 prisca, Leiofusa tanaocyta, Leiosphaeridia laevigata, L. microcystis and L. wenlockia,

274 some scolecodonts, the cryptospore Tetrahedraletes medinensis and cuticles (Li et al.

275 1997). Xing and Fang (1999) reported acritarch assemblages in the Qilang and lower

276 Kalpingtag formations. They attributed the Qilang Formation to the Upper Ordovician

277 and the lower Kalpingtag Formation to the Silurian (Xing and Fang 1999). The lower

278 member of the Kalpingtag Formation was distinguished and renamed as the

279 Tierekeawati Formation (Huang et al. 2009). Later, the Tierekeawati Formation was

280 confined to the lower and middle parts of the lower member of the former Kalpingtag

281 Formation, and was assigned to the Upper Ordovician (Tang et al. 2012). Therefore,

282 the acritarch assemblage described in Xing and Fang (1999) is not considered to be

283 Silurian, but of Ordovician age. Yao et al. (2006) reported the acritarchs

284 Leiosphaeridia, Priscogalea and Florisphaeridium, as well as chitinozoans, in the

285 lower to middle part of the Wenquangou Group from the West Kunlun Mountains and

286 attributed this palynomorph assemblage to the 'Early Silurian' (Fig 1, Location 17). 
288 Junggar

289 The Junggar Block is a part of the Kazakhstan Palaeoplate and two papers reported

290 Silurian acritarch assemblages in that area. Ye (1984) described a late Llandovery to

291 Wenlock palynomorph assemblage including acritarchs, spores, chitinozoans and

292 scolecodonts. Deunffia, Mutiplicisphaeridium, Baltisphaeridium and Micrhystridium

293 were found, and attributed to the Deunffia-Domasia assemblage (Fig 1, Location 18).

294 Gao (1993) recognized four spore zones in the late Silurian-Early Devonian from the

295 Sharburti Mountains, western Junggar (Fig 1, Location 19). The first spore zone, DS

296 (Synorisporites dittonensis-apiculiretusispora spicula) Zone, was referred to the late

297 Silurian. The palynomorph assemblage corresponding to the DS Zone mainly consists

298 of spores, and about 25\% acritarchs, including 15 genera and 18 species. The other

299 spore zones are Devonian.

300

301

Conclusions

302

303

from six palaeoplates or blocks, although two of them have since been confirmed to

304

be Ordovician assemblages. Most research has focused on acritarchs from South

305

China and from the Llandovery period. We have updated the systematics of the taxa

in these reported assemblages and documented their biostratigraphic distribution

307

within China. Silurian acritarch studies in China are far from being comprehensive;

more investigations on Silurian acritarch assemblages in China are needed for 
309

310

311

312

313

314

315

316

317

318

319

320

321

322

323

324

325

326

327

328

329

330

systematic, biostratigraphic, and palaeoecological interpretations.

\section{Acknowledgements}

We thank the referees and Associate Editor Dr. Mike Melchin for revising the

manuscript and providing very useful suggestion. We acknowledge funding from several Chinese projects (NSFC41272012, 41472007, 41521061 and 41290260). This is a contribution to the IGCP project 591.

\section{Appendix}

Chinese Silurian acritarch stratigraphic distribution. The number shows in the right column refer to the location in figure 1 . All acritarch taxa have been revised following Fensome et al., 1990 to remove the invalid taxa and combine taxonomic synonym.

\section{References}

Cramer, F.H. 1971. Distribution of selected Silurian acritarchs. Revista Española Micropaleontología, Numero Extraordinario, 1: 1-203.

Cramer, F.H.and Díez, M. del C. R. 1972. North American Silurian palynofacies and their spatial arrangement: acritarchs. Palaeontographica, Abteilung B, 138: 107-180.

Cramer, F.H. and Díez, M. del C.R. 1974a. Early Paleozoic palynomorph provinces and paleoclimate. In Paleogeographic Provinces and Provinciality, Special Publications, 21. Edited by C.A. Ross. Society of Economic Paleontologists and 

Mineralogists, Tulsa, OK. pp. 177-188.

Cramer, F.H. and Díez, M. del C.R. 1974b. Silurian acritarchs: distribution and trends. Review of Palaeobotany and Palynology, 18: 137-154.

Fang, X. 1989. Silurian microflora from Guanyinqiao, Qijiang, Sichuan. Acta Micropalaeontologica Sinica, 6: 301-310 (in Chinese with English abstract).

Fang, X., and He, S. 1988. The microflora of the Tangjiawu Formation in western Zhejiang Province and its chronologic significance. Geological Review, 34: 327-333 (in Chinese with English abstract).

Fang, X., and Hou, J. 1988. Silurian microflora and chitinozoa in Guanyinqiao, Qijiang County, Sichuan Province, and their stratigraphic significance. Professional Paper of Stratigraphy and Palaeontology, 20: 198-209 (in Chinese with English abstract).

Fensome, R.A., Williams, G.L., Barss, M.B., Freeman, J.M., Hill, J.M. 1990. Acritarchs and fossil prasinophytes: an index to genera, species and infraspecific taxa. AASP Contributions Series Number 25: 1-771.

Gao, L. 1993. Late Silurian-Early Devonian spores and acritarchs from West Junggar. Xinjiang Geology, 11: 192-203 (in Chinese with English abstract).

Gao, L. 1996. Late Silurian-Early Devonian spores, acritarchs from Shidian, West Yunnan. Acta Geoscientia Sinica, 17: 105-141 (in Chinese with English abstract).

Gao, L., and Ye, X. 1987. Late Silurian and Devonian spores from west Qinling Mountains, China. In Late Silurian-Devonian Strata and Fossils from Luqu-Tewo Area of West Qinling Mountains, China, vol. 2. Edited by Xian Institute of 
Geology and Mineral Resources, China Academy of Geology Science and Nanjing Institute of Geology and Palaeontology, Chinese Academy of Sciences. Nanjing University Press, Nanjing. pp. 379-450 (in Chinese with English abstract).

Guo L. 2012. Sedimentary characteristics of Silurian Longmaxi Black Shale and its significance for shale gas in southeast of Chongqing. PHD thesis, China University of Geosciences, Beijing.

Huang, Z.B., Deng, S.H., Du, P.D., Zhang, S.B., Tan, Z.J., Lu, Y.Z., Yang, Z.L., Dong, B.Q., Yang, X.M., and Jing, X.C. 2009. New advances in stratigraphic study on Ordovician in Tarim Basin. In Paper Collection for the 20 Years Anniversary of Tarim Petroleum Meeting Campaign (Exploration Vol.). Edited by X.Y. Zhou. Petroleum Industry Press, Beijing. pp. 172-186 (in Chinese).

Le Hérissé, A., Gourvennec, R. 1995. Biogeography of upper Llandovery and Wenlock acritarchs. Review of Palaeobotany and Palynology, 86: 111-133.

Le Hérissé, A., Gourvennec, R., Wicander, R. 1997. Biogeography of Late Silurian and Devonian acritarchs and prasinophytes. Review of Palaeobotany and Palynology, 98: 105-124.

Li, J., and Wang, Y. 1997. Acritarchs from the Early Silurian Ningqiang Formation (Later Llandovery) of Ningqiang, Shaanxi, China. Acta Palaeontologica Sinica, 36: 358-372 (in Chinese with English abstract).

Li, J., Zhu, H., and Fang, Z. 1997. Microfossils from the Silurian Tataaiertage Formation of Kalpin, Xinjiang. Acta Palaeontologica Sinica 36: 136-143 (in Chinese with English abstract). 
375 Li, J., Wang, Y., Qi, Y., and Zhu, Y. 2000. Late Ludlow-Early Pridoli palynomorphs 376 from Northern Jiangsu, South China. In Palynofloras and Palynomorphs of China. 377 Edited by Z. Song. Press of University of Science and Technology of China, Hefei. $378 \quad$ pp. $138-143$.

379 Li, J., Servais, T., and Brocke, R. 2002. Chinese Paleozoic acritarch research: review 380 and perspectives. Review of Palaeobotany and Palynology, 118: 181-193.

Li, J., Wicander, R., Yan, K., Zhu, H. 2006. An Upper Ordovician acritarch and prasinophyte assemblage from Dawangou, Xinjiang, northwestern China: Biostratigraphic and paleogeographic implications. Review of Palaeobotany and Palynology, 139: 97-128.

Li, W. 1990. Preliminary study of fossils in kerogen samples from Silurian in southern Sichuan. Experimental Petroleum Geology, 12: 333-337 (in Chinese with English abstract).

Liu, Y. 1993. Discovery of Silurian microflora fossils from 'Junying Group' of West Hainan Island. Regional Geology of China, 1993: 94-95 (in Chinese).

Melchin, M.J., Sadler, P.M., Cramer, B.D., Cooper, R.A., Gradstein, F.M., and Hammer, O. 2012. Chapter 21: The Silurian Period. In The Geologic Time Scale 2012. Edited by F.M. Gradstein, J. G. Ogg, M. D. Schmitz, and G.M. Ogg. Elsevier, Amsterdam. pp. 525-558.

Molyneux, S.G., Delabroye, A., Wicander R., and Servais, T. 2013. Chapter 23 395 Biogeography of early to mid Palaeozoic (Cambrian-Devonian) marine phytoplankton. Geological Society, London, Memoirs 2013, 38: 365-397. 
397

398

Mu, E., Boucot, B.J., Chen, X., and Rong, J. 1986. Correlation of the Silurian rocks of China (A part of the Silurian correlation for East Asia). Special Paper of the Geological Society of America, 202: 1-80.

Rong, J., and Chen, X. 1990. Present and past of Silurian researches in China. Acta Palaeontologica Sinica, 29: 385-401 (in Chinese with English abstract).

Rong, J., and Chen, X. 2000. Comments on Silurian Chronostratigraphy of China. Journal of Stratigraphy, 24: 27-35.

Rong, J., and Chen, X. 2003. Silurian biostratigraphy of China. In Biostratigraphy of China. Edited by W. Zhang, P. Chen, and A. R. Palmor. Science Press, Beijing. pp. 173-226.

Rong, J., Chen, X., Su, Y., Ni, Y., Zhan, R., Chen, T., Fu, L., Li, R., and Fan, J. 2003. Silurian paleogeography of China. In Silurian lands and seas - Paleogeography outside of Laurentia. Edited by M. E. Johnson, and E. Landing. New York State Museum, New York. pp. 243-298.

Strother, P.K. 1996. Acritarchs. In Palynology: Principles and Applications, Vol. 1. Edited by J. Jansonius, and D.C. Mcgregor., American Association of Stratigraphic Palynologists Foundation, Publishers Press, Salt Lake City, Utah. pp. 81-106.

Tappan, H., and Loeblich, A.R.Jr. 1973. Evolution of the Oceanic Palankton. Earth Science Review, 9: 207-240.

Tang, P., Cai, X.Y., and Liang, Y. 2012. Late Ordovician-Early Silurian chitinozoans in the Keping area, Tarim. In Abstract volume on 9th Congress and 14th Annual 
Meeting of the Micropalaeontological Society of China and 7th Congress and 15th Annual Meeting of Committee on Fossil Algae. pp. 40-41.

Tang, P., Wang, J., Wang, C., Wu, R., Yan, K., Liang, Y., and Wang, X. 2015. Microfossils across the Llandovery-Wenlock boundary in Ziyang-Langao region, Shaanxi, NW China. Palaeoworld, 24: 221-230.

Tian, J., Zhu, H., Huang, M., and Liu, F. 2011. Late Silurian to Early Devonian Palynomorphs from Qujing, Yunnan, Southwest China. Acta Geologica Sinica, 85: $559-568$.

Torsvik, T.H., and Cocks, L.R.M. 2013. Chapter 2 New global palaeogeographical reconstructions for the Early Palaeozoic and their generation. Geological Society, London, Memoirs 2013, 38: 5-24.

Wang, G., and Zhang, C. 1985. On the geological age of the Xiaoxiyu Formation, northwestern Hunan. Bulletin Yichang Institute Geology and Mineral Resoures, Chinese Academy of Geological Sciences, 10: 35-46 (in Chinese with English abstract).

Wang, G., Geng, L., Xiao, Y., and Zhu, Z. 1988. Geological age and depositional feature of the upper Xiushan and Xiaoxiyu formations of west Hunan. Journal of Stratigraphy, 12: 216-225 (in Chinese with English abstract).

Wang, Y., and Li, J. 2001. Upper Silurian "phytodebris" from north Jiangsu, China. Acta Palaeontologica Sinica, 40: 51-60.

Wang, Y., and Ouyang, S. 1997. Discovery of Early Silurian spores from Fenggang, northern Guizhou, and its palaeobotanical significance. Acta Palaeontologica 
Sinica, 36: 217-236 (in Chinese with English abstract).

442 Wang, Y., Zhu, H., and Li, J. 2005. Late Silurian plant microfossil assemblage from

443 Guangyuan, Sichuan, China. Review of Palaeobotany and Palynology, 133:

$444 \quad 153-168$.

445 Wang, Y., Rong, J., Xu, H., Wang, C., and Wang, G. 2010. On the late Silurian 446 stratigraphy of the Zhangjiajie area, Hunan province, with a discussion on age of 447 the Xiaoxi Formation. Journal of Stratigraphy, 34: 113-126.

448 Wang, Y., Zhang, X., Xu, H., Jiang Q., and Tang, P. 2011. Discovery of the Late 449 Silurian Xiaoxi Formation in the Xiushan area, Chongqing City, China, and the 450 revision of the Huixingshao Formation. Journal of Stratigraphy, 35: 113-121 (in $451 \quad$ Chinese with English abstract).

452 Xing, Y., and Fang, X. 1999. Ordovician-Silurian micropaleoflora from Keping region, 453 Xinjiang and its stratigraphical significance. Professional Paper of Stratigraphy 454 and Palaeontology, 27: 125-134 (in Chinese with English abstract).

455 Xing, Y., and Liu, G. 1985. Microflora from the Ordovician and Silurian in the 456 Xilingxia region, Yangzi Gorges. In Selected papers from the First National fossil 457 algal symposium. Edited by Committee on Fossil Algae, Palaeontological Society 458 of China. Geological Publishing House, Beijing. pp. 145-154 (in Chinese).

459 Yan, T. 1991. The microflora assemblages character and their age of Tangjiawu and 460 Xihu formations in Hangzhou region, Zhejiang Province. Geology of Zhejiang, 7: $461 \quad$ 28-33 (in Chinese with English abstract).

462 Yan, T. 1992. The microflora of the Tangjiawu and Xihu Formations in Zhejiang and 
their stratigraphical division and correlation. Regional Geology of China, 1992: 111-117 (in Chinese with English abstract).

Yan, T., He, S., Yin, L., Qin, X., and Zhang, Z. 2011. Early Paleozoic palynomorphs of Zhejiang Province, China. Journal of Stratigraphy, 35: 19-30.

467

Yao, J., Xiao, X., Gao, L., Han, F., Cui, J., Peng, H., Ji, Z., and Wu, G. 2006. Silurian acritarchs and chitinozoans in Wenquangou Group from the west Kunlun region. Acta Palaeontologica Sinica, 45: 528-532.

Ye, X. 1984. Microfossil assemblage from Silurian of Kumyezekat Toli, NW Xinjiang, and their stratigraphic significance. Bulletin of Xian Institute of Geology and Mineral Resources, China Academy of Geology Science, 7: 39-49 (in Chinese with English abstract).

Yin, Z. 1949. Tentative classification of Silurian rocks of South China. Bulletin of the Geological Society of China, 29: 1-61.

Yin, L., and He, S. 2000. Palynomorphs from the transitional sequences between Ordovician and Silurian of northwestern Zhejiang, South China. In Palynofloras and Palynomorphs of China. Edited by Z. Song. Press of University of Science and Technology of China, Hefei. pp. 186-202.

Yin, L., Yuan, X., Zhang, J., and Fu, Z. 1993. Acritarch assemblages from Dongzhuang Shale in southwestern margin of Ordos Basin and its geological age. Palaeoworld, 2: 175-183 (in Chinese).

Zhong, G. 1978. Sinian and Silurian Micropalaeoflora. In Paleontological Atlas of Central-Southern China, vol. 4, Microfossils. Hubei Institute of Geological 
485

486

487

488

489

490

491

492

493

494

495

496

497

498

499

500

501

502

503

504

505

506

Sciences, Edited by Hubei Institute of Geosciences. Geological Publishing House, Beijing. pp. 382-390 (in Chinese).

Zhou, W., Jiang, S., Xu, Y., Zhu, Z., Xiong, Y., and Bian, L. 2013. Acritarch fossil and detrital zircon geochronology study of the Xikeng Formation, Silurian, in Jiurui metallogenic district, Jiangxi Province. Acta Petrologica Sinica, 29: 4281-4290 (in Chinese with English abstract).

Zhou W. 2014. Acritarch fossils, detrital zircon geochronology and depositional environment study of the Xikeng Formation, Silurian, in Jiurui metallogenic district, Jiangxi Province. MSc thesis, Nanjing University, Nanjing.

\section{Figure caption}

Figure 1 Map of Silurian tectonic units of China with boundaries of various palaeoplates or blocks. Black dots show sections from which acritarchs have been reported. Modified from Rong and Chen, 2003.

1. Anji, Chun'an, Fuyang, Lin'an, Tonglu, Xiaoshan, Zhejiang (Fang and He, 1988; Yan, 1991, 1992; Yan et al., 2011; Yin and He, 2000); 2. Zigui, Hubei (Zhong, 1978; Xing and Liu, 1985); 3. Hainan (Liu, 1993); 4. Qijiang, Chongqing (Fang and Hou,1988; Fang, 1989); 5. Ningqiang, Shaanxi (Li and Wang, 1997); 6. Baojing, Sangzhi, Zhangjiajie, Hunan (Wang and Zhang, 1985; Wang et al., 1988); 7. Jiujiang, Jiangxi (Zhou et al., 2013); 8. Ziyang, Shaanxi (Tang et al., 2015); 9. Guangyuan, Sichuan (Wang et al., 2005); 10. Xiushan, Chongqing (Wang et al., 2011); 11. Dafeng, 
507 Jiangsu (Li et al., 2000; Wang and Li, 2001); 12. Tewo, Gansu; Zoige, Sichuan (Gao

508 and Ye, 1987); 13. Qujing, Yunan (Tian et al. 2011); 14. Shidian, Yunnan (Gao, 1996);

509 15. Liquan, Shaanxi (Yin et al., 1993); 16. Kalpin, Xinjiang (Li et al., 1997; Xing and

510 Fang, 1999); 17. West Kunlun, Xinjiang (Yao et al., 2006); 18. Toli, Xinjiang (Ye,

511 1984); 19. Sharburti Mountains, Xinjiang (Gao, 1993)

512

513 Figure 2. Silurian stratigraphic framework in China (Modified from Rong et al., 2003;

514 Wang et al., 2010). 1. Cuijiagou Formation; 2. Xitun Formation; 3. Xiaxishancun

515 Formation.

516

517 Figure 3. Overview of Chinese localities and stratigraphy from which Silurian

518 acritarchs have been reported. Numbers referring to acritarch assemblages are the 519 same as in Fig. 1. 


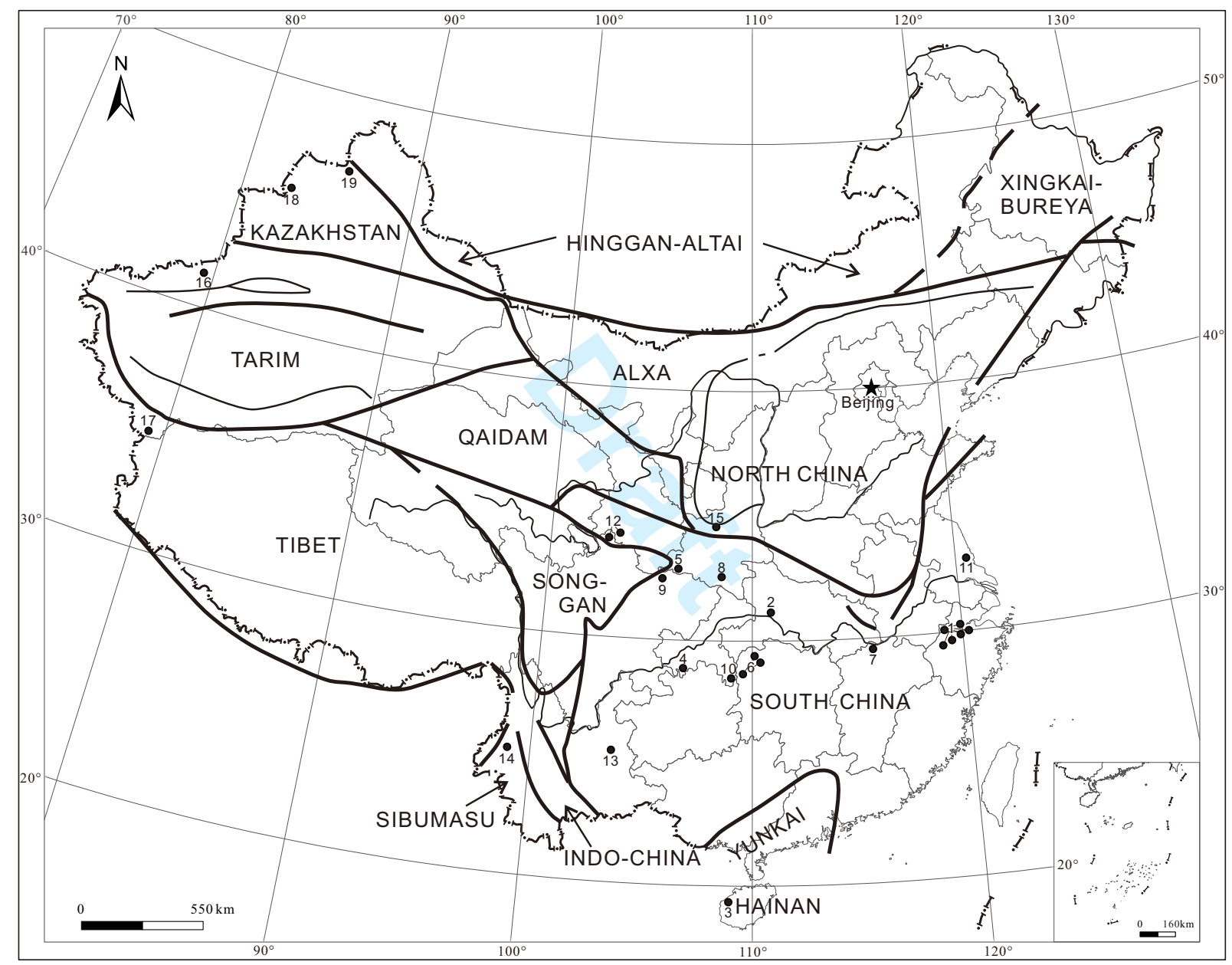




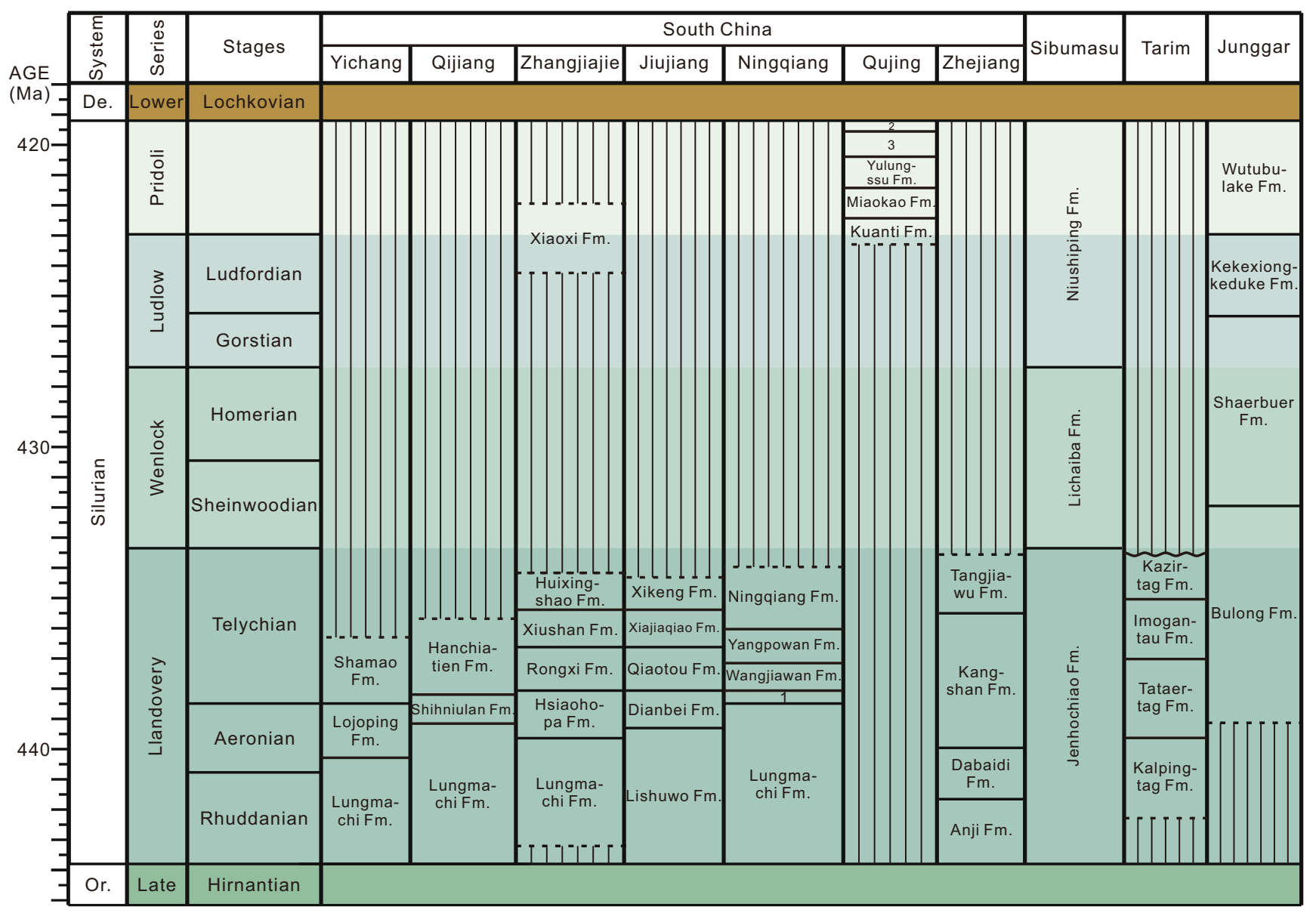




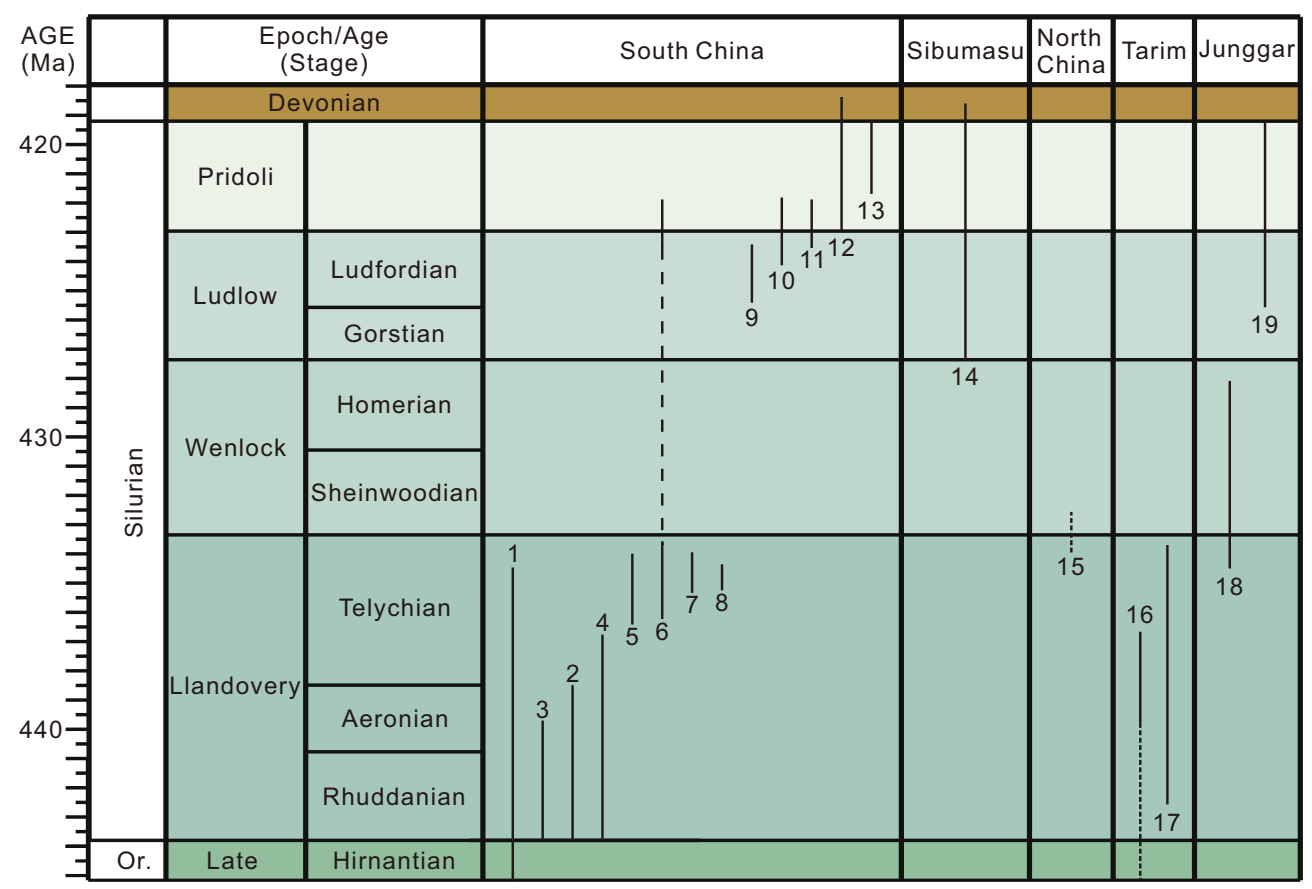

